\title{
KONTRIBUSI PEMBELAJARAN KEWIRAUSAHAAN TERHADAP MINAT BERWIRAUSAHA PADA BIDANG OTOMOTIF
}

\author{
Yadi Supriyadi ${ }^{1}$, Inu Hardi Kusumah ${ }^{2}$, Tatang Permana ${ }^{3}$ \\ Departemen Pendidikan Teknik Mesin \\ Universitas Pendidikan Indonesia \\ Jl. Dr. Setiabudhi No. 207 Bandung 40154 \\ yadi_89@yahoo.com
}

\begin{abstract}
ABSTRAK
Penelitian ini bertujuan untuk mengetahui besarnya kontribusi pembelajaran praktek kerja industri terhadap minat berwirausaha siswa di SMK Negeri 8 Bandung. Metode yang digunakan adalah metode deskriptif. Teknik pengumpulan data berupa angket dan studi dokumentasi. Hasil penelitian menunjukkan bahwa tingkat pelaksanaan pembelajaran praktek kerja industri dalam kategori cukup baik. Minat berwirausaha siswa di SMK dalam kategori sedang. Berdasarkan hasil pengujian koefisien determinasi antara pembelajaran praktek kerja industri dan minat berwirausaha sebesar 18,5\%. Besarnya kontribusi dari pembelajaran praktek kerja industri terhadap minat berwirausaha pada bidang otomotif berkategori sedang.
\end{abstract}

Kata kunci: pembelajaran, praktek kerja, industri, minat

\begin{abstract}
This study aims to determine the relationship of industry practices to the interest in entrepreneurship teaching students in SMK Negeri 8 Bandung. The method used in this research is descriptive method. Data collection techniques such as questionnaires and the documentation. The results shows that the level of implementation of entrepreneurial learning classified in the category quite well. The interest in industry practices the middle category. The results obtained coefficient of determination between entrepreneurial learning and interest in industry practices $18.5 \%$. The relationship of entrepreneurial learning to interest in industry practices in the field is in the middle category.
\end{abstract}

Keywords: learning, industry, practices, interests

\section{PENDAHULUAN}

Visi dari sekolah SMK N 8 Bandung adalah menjadi sekolah unggulan yang menghasilkan tamatan berkualitas, sebagai mekanik/tenaga kerja yang kompeten, wirausahawan yang sukses dan melanjutkan ke perguruan tinggi melalui pengembangan IPTEK dan IMTAQ. Prioritas utama lulusannya adalah yang pertama untuk bekerja, yang kedua wirausaha dan terakhir adalah untuk melanjutkan kuliah ke perguruan tinggi.

\footnotetext{
${ }^{1}$ Mahasiswa Departemen Pendidikan Teknik Mesin FPTK UPI

${ }^{2}$ Dosen Departemen Pendidikan Teknik Mesin FPTK UPI

${ }^{3}$ Dosen Departemen Pendidikan Teknik Mesin FPTK UPI
} 
Ketercapaian tujuan dan visi dari SMK N 8 Bandung akan terlihat dengan sejauh mana lulusan bisa bekerja, berwirausaha dan melanjutkan kuliah dengan baik.

Tabel data penelusuran tamatan SMK Negeri 8 Bandung diatas, menunjukan bahwa lulusan yang berwirausaha di sekolah tersebut masih rendah dibandingkan dengan yang bekerja di instansi pemerintah ataupun melanjutkan ke perguruan tinggi. Melihat kenyataan yang dihadapi tersebut, terdapat kesenjangan antara harapan dengan kenyataan, dimana harapannya adalah lulusan sekolah seharusnya lebih banyak yang berwirausaha dibandingkan dengan yang melanjutkan ke perguruan tinggi. Kenyataan yang terjadi lulusan dari SMK N 8 Bandung lebih banyak yang melanjutkan sekolah ke perguruan tinggi dibandingkan dengan yang berwirausaha. Permasalahan tersebut perlu diatasi dengan menggunakan sebuah solusi. Salah satu caranya adalah dengan berwirausaha. Wirausahawan (enterpreneur) adalah seseorang yang bebas dan memiliki kemampuan hidup mandiri dalam menjalankan usaha atau industrinya sendiri, sesuai dengan bidang yang dikuasai. Permasalahan minat berwirausaha berkaitan dengan banyak faktor baik dari diri peserta didik (internal) misalnya prestasi belajar, motivasi, sikap, minat, maupun kondisi fisiologis seperti kesehatan dan panca indera. Contohnya adalah kurangnya pandangan peserta didik pada dunia wirausaha dan kurangnya keinginan dari peserta didik itu sendiri untuk membuka usaha maupun dari faktor dari luar diri peserta didik itu sendiri (Eksternal), misalnya dari, pengalaman, peluang, lingkungan sekolah, lingkungan sekitar peserta didik lingkungan masyarakat atau dari lingkungan keluarga peserta didik.

Pengaruh faktor pengalaman sebagai salah satu faktor eksternal yang dapat menumbuhkan minat seseorang untuk berwirausaha. Sebagai pendalaman wirausaha untuk itu, peserta didik disini sangat membutuhkan pembelajaran sebelumnya agar mendapatkan pengalaman dan kemampuan terkait dengan kewirausahaan. Dengan demikian sekolah sebagai lembaga pendidikan (SMK) diharapkan mampu membekali peserta didik dengan berbagai bentuk pengalaman melalui pembelajaran yang berhubungan dengan kewirausahaan

Pendidikan sistem ganda diharapkan dapat menciptakan tenaga kerja yang profesional. Peserta didik yang melaksanakan pendidikan tersebut diharapkan dapat menerapkan ilmu yang didapat dan sekaligus mempelajari dunia industri, dalam rangka merealisasikan pendidikan sistem ganda tersebut, salah satu upaya yang dapat dilakukan adalah melalui praktik kerja industri yaitu suatu kegiatan pendidikan dan latihan kerja dengan mengembangkan 
kemampuan, keahlian dan profesi ditempat kerja sesuai dengan bidang studi atau jurusan masing-masing peserta didik. Penelitian ini bertujuan untuk mengetahui hasil pengalaman praktik kerja industri dan minat wirausaha siswa SMK. Besaran hubungan hasil praktek industri terhadap minat berwirausaha siswa di SMK.

Perbuatan yang mengarahkan kepada suatu tujuan dan merupakan suatu dorongan hasil interaksi dengan dunia luar, berupa keingintahuan dan rasa senang terhadap apa yang diminatinya (Purwanto, 2006). Dalam diri manusia terdapat dorongan-dorongan dan keinginan yang mendorong manusia untuk berinteraksi dengan dunia luar, dan apa yang sudah menjadi minat seseorang mendorongnya untuk berbuat lebih giat dan lebih baik. Wirausaha adalah orang-orang yang mempunyai kemampuan melihat dan menilai kesempatan-kesempatan bisnis, berorientasi ke masa depan yang dibuktikan dengan kesungguhan untuk mengumpulkan sumber-sumber daya yang dibutuhkan guna mengambil keuntungan dan tindakan yang tepat guna dalam memastikan kesuksesan (Ating, 2004). Minat berwirausaha pada bidang otomotif yaitu dorongan dan keinginan untuk melakukan kegiatan perintisan usaha di bidang otomotif didasari atas keingintahuan, rasa senang, berorientasi masa depan, serta memiliki kesungguhan untuk terlibat dalam dalam pengembangan minat terhadap kegiatan perintisan usaha pada bidang otomotif.

Peran pembelajaran praktek kerja indusdtri diperlukan untuk membangun minat dalam berwirausaha. Proses identifikasi dan proses belajar turut membentuk minat, sehingga kegiatan belajar di sekolah dapat mempengaruhi pertumbuhan minat. Untuk membentuk sikap kewirausahaan, termasuk didalamnya minat berwirausaha, adalah mulai dengan tahap pemahaman teori, studi kasus, dan pemberian motivasi, ketiga tahapan ini dapat dilakukan di lingkungan sekolah.

\section{METODE PENELITIAN}

Metode penelitian yang digunakan yaitu deskriptif. Deskripsi yang dimaksud yaitu mengenai pembelajaran praktek kerja industri dan minat berwirausaha siswa. Kemudian diuji apakah pembelajaran praktek kerja industri memiliki hubungan terhadap minat berwirausaha siswa. Jumlah populasi dalam penelitian ini sebanyak 213 peserta didik. Pengambilan sampel menggunakan metode simple random sampling dengan ukuran sampel minimalnya sebanyak 49 menjelaskan hubungan kausal dan pengujian hipotesa peserta didik. Pengumpulan data 
yang digunakan yaitu angket, studi literatur, dan studi dokumentasi. Data yang terkumpul selanjutnya diuji validitas dan realibilitasnya. Data dalam bentuk ordinal diubah ke dalam bentuk interval dengan menggunakan Methods of Successive Interval (MSI). Teknik analisis data menggunakan regresi linier sederhana.

\section{HASIL PENELITIAN}

Hasil akhir pembelajaran praktek kerja industri pada siswa kelas XII TKR SMK Negeri 8 Bandung, berdasarkan nilai kategori kecenderungan (Tabel 1).

Tabel 1. Kecenderungan pembelajaran praktek kerja industri

\begin{tabular}{ccc}
\hline Kategori & Jumlah Siswa & Persentase \\
\hline Tidak Baik & 5 & 10 \\
Kurang Baik & 13 & 27 \\
Cukup Baik & 18 & 37 \\
Baik & 11 & 22 \\
Sangat Baik & 2 & 4 \\
Jumlah & 49 & 100 \\
\hline
\end{tabular}

Pembelajaran praktek industri terdapat 5 siswa yang memiliki kriteria tidak baik dengan persentasi 10\%, 13 siswa memiliki kriteria kurang baik dengan persentase 27\%, 18 siswa memiliki kriteria cukup baik dengan persentase 37\%, 11 siswa berkriteria baik dengan persentase $22 \%$ dan 2 siswa berkriteria sangat baik dengan persentase 4\%. Hal tersebut menunjukan bahwa mayoritas siswa kelas XII TKR SMK Negeri 8 Bandung telah melaksanakan pembelajaran praktek industri dengan hasil akhir yang cukup baik.

Minat berwirausaha pada bidang otomotif siswa SMK Negeri 8 Bandung. Minat berwirausaha di bidang otomotif terdapat 15 siswa yang memiliki kriteria sangat rendah dengan persentasi 30\%, 10 siswa memiliki kriteria rendah dengan persentase 20\%, 18 siswa memiliki kriteria sedang dengan persentase 37\%, 6 siswa berkriteria tinggi dengan persentase $12 \%$ dan 5 siswa berkriteria sangat tinggi dengan persentase $10 \%$. Hal tersebut menunjukkan bahwa mayoritas siswa SMK Negeri 8 Bandung memiliki minat yang sedang untuk menjadi seorang wirausaha di bidang otomotif. 
Tabel 2. Minat berwirausaha pada bidang otomotif

\begin{tabular}{ccc}
\hline Kategori & Jumlah Siswa & Persentase \\
\hline Sangat Rendah & 6 & 8 \\
Rendah & 13 & 18 \\
Sedang & 21 & 30 \\
Tinggi & 19 & 27 \\
Sangat Tinggi & 12 & 17 \\
Jumlah & $\mathbf{7 1}$ & 100 \\
\hline
\end{tabular}

Minat berwirausaha di bidang otomotif terdapat 6 siswa yang memiliki kriteria sangat rendah dengan persentasi 8\%, 13 siswa memiliki kriteria rendah dengan persentase 18\%, 21 siswa memiliki kriteria sedang dengan persentase 30\%, 19 siswa berkriteria tinggi dengan persentase $27 \%$ dan 12 siswa berkriteria sangat tinggi dengan persentase $17 \%$. Hal tersebut menunjukkan bahwa mayoritas siswa kelas XII TSM SMK Negeri 8 Bandung memiliki minat yang sedang untuk menjadi seorang wirausaha di bidang otomotif.

Diketahui bahwa nilai koefisien korelasi antara variabel pembelajaran praktek kerja industri dengan minat berwirausaha sebesar 0,431. Apabila di interpretasi ke dalam tabel interpretasi koefisien korelasi. Hasil korelasi tersebut berada dalam kategori "sedang" dengan arah hubungan yang linear positif. Hasil uji t bahwa pembelajaran praktek kerja industri memiliki $t_{\text {hitung }}>t_{\text {tabel }}(3,271>1,667)$. Hasil tersebut dapat diartikan yakni menolak Ho dan menerima Ha. Ini berarti bahwa pembelajaran praktek kerja industri mempunyai hubungan terhadap minat berwirausaha pada bidang otomotif.

Hasil perhitungan koefisien determinasi $\left(\mathrm{R}^{2}\right)$ yaitu angka yang menunjukkan seberapa besar variabel praktek kerja industri secara parsial dan simultan berpengaruh terhadap variabel minat wirausaha. Berdasarkan hasil perhitungan didapat koefisien determinasi sebesar 0,185 atau $18,5 \%$. Interpretasi pada tabel koefisien determinasi, hasil tersebut menunjukkan kategori sedang. Besarnya nilai determinasi menunjukkan bahwa besarnya hubungan praktek kerja industri terhadap variabel minat berwirausaha pada bidang otomotif adalah sebesar 18,5\% sedangkan sisanya $81,5 \%$ dipengaruhi oleh variabel lain yang tidak dibahas dalam penelitian ini. 


\section{PEMBAHASAN}

Hasil penelitian yang diperoleh dalam pembelajaran praktek kerja industri, dari 49 siswa terdapat 5 siswa yang memiliki kriteria tidak baik dengan persentasi 10\%, 13 siswa memiliki kriteria kurang baik dengan persentase 27\%, 18 siswa memiliki kriteria cukup baik baik dengan persentase $37 \%, 11$ siswa berkriteria baik dengan persentase $22 \%$ dan 2 siswa berkriteria sangat baik dengan persentase 4\%. Data tersebut merupakan temuan yang menunjukkan sebagai gambaran atau tingkat pelaksanaan pembelajaran praktek industri di kalangan siswa tergolong cukup baik. Hasil tersebut menyatakan bahwa kebanyakan peserta didik sudah memiliki kesiapan pembelajaran praktek kerja industri tersebut berada dalam kategori sedang. Pelaksanaan pembelajaran praktek kerja industri tegolong dalam kategori cukup baik. Hasil tersebut menyatakan bahwa rata-rata siswa yang telah melaksanakan pembelajaran praktek kerja industri di SMK Negeri 8 Bandung telah mengalami proses dan hasil yang cukup baik.

Minat berwirausaha pada bidang otomotif di kalangan siswa menunjukan bahwa dari 49 siswa didapat hasil sebanyak 15 siswa (30\%) kategori sangat rendah, 10 siswa (20\%) termasuk kategori rendah, 18 siswa (37\%) kategori wirausaha sedang, 6 siswa (13\%) kategori berwirausaha tinggi, dan 10 siswa (10\%) kategori sangat baik.

Minat berwirausaha pada bidang otomotif di kalangan siswa berada pada kategori sedang. Hasil tersebut menyatakan bahwa mayoritas dari kebanyakan siswa sudah memiliki minat berwirausaha pada bidang otomotif, namun minat berwirausaha tersebut berada dalam kategori sedang. Tingkat minat berwirausaha berada pada kategori sedang ini diukur berdasarkan adanya keingintahuan, perasaan senang, berorientasi ke masa depan dan kesungguhan untuk terlibat dalam pengembangan minat terhadap kegiatan perintisan usaha di bidang otomotif (Tedjasutisna, 2004).

Pembelajaran praktek industri berhubungan positif terhadap minat berwirausaha pada bidang otomotif. Hubungan antara praktek kerja industri terhadap variabel Y dapat dilihat pada persamaan regresi: $\hat{Y}=4,54+0,539 \mathrm{X}$. Arti persamaan regresi ini yaitu jika terjadi perubahan atau peningkatan satu kesatuan unit praktek kerja industri akan menyebabkan minat berwirausaha pada bidang otomotif berubah atau meningkat sebesar 0,539 unit satuan. Sehingga meningkatnya nilai pembelajaran praktek industri akan diikuti meningkatnya minat berwirausaha siswa pada bidang otomotif. Hasil uji keberartian regresi didapat nilai signifikan 
$0,02<0,05$. Hasil perhitungan ini menjelaskan terdapat hubungan yang linier antara praktek kerja industri dengan minat berwirausaha pada bidang otomotif, dengan kata lain semakin baik siswa melaksanakan pembelajaran praktek industri, maka akan semakin tinggi minat berwirausaha pada bidang otomotif.

Koefisien korelasi diperoleh sebesar 0,431. Hasil perhitungan ini menjelaskan bahwa pembelajaran pratek kerja industri yang dialami siswa mempunyai korelasi sedang terhadap minat berwirausaha pada bidang otomotif. Hasil perhitungan koefisien korelasi tersebut diyakinkan dengan uji signifikansi koefisien korelasi dengan menghitung nilai t, dimana hitung $>\mathrm{t}$ tabel $(3,217>1,667)$, sehingga dapat diartikan menolak Ho dan menerima Ha, atau pembelajaran praktek industri behubungan positif terhadap minat berwirausaha pada bidang otomotif.

Berdasarkan temuan hasil penelitian menunjukkan bahwa pembelajaran praktek kerja industri memiliki hubungan positif terhadap minat berwirausaha pada bidang otomotif, dengan diketahui nilai koefisien Determinasi $\left(\mathrm{R}^{2}\right)$ sebesar 0,185 atau 18,5\%. Angka tersebut menunjukkan bahwa besarnya hubungan variabel pembelajaran praktek industri terhadap variabel minat berwirausaha pada bidang otomotif adalah sedang yaitu sebesar 18,5\%, sedangkan sisanya $81,5 \%$ dipengaruhi oleh variabel lain.

\section{KESIMPULAN}

Kesimpulan penelitian ini adalah pembelajaran praktek industri di kalangan siswa SMK tergolong cukup baik, artinya siswa telah melaksanakan pembelajaran praktek industri dengan cukup baik. Minat berwirausaha pada bidang otomotif di kalangan siswa berkategori sedang. Artinya siswa sudah mempunyai minat berwirausaha pada bidang otomotif, dimana minat tersebut berada dalam kategori sedang. Pembelajaran kewirausahaan mempunyai hubungan positif terhadap minat berwirausaha pada bidang otomotif.

\section{DAFTAR PUSTAKA}

Purwanto, N. (2006). Psikologi Pendidikan. Bandung: PT Remaja Rosdakarya.

Rohani, A (2010). Pengelolaan Pengajaran. Jakarta: Rineka Cipta

Tedjasutisna, A. (2004). Memahami Kewirausahaan. Bandung :Armico 